\title{
Teacher and Student Perception through Online Literature Circle on Reading Comprehension: a Phenomenology Study
}

\author{
Musdalifah $^{1}$ \\ ${ }^{1}$ Ibrahimy University, , Indonesia \\ (lifamudalifa.sit@gmail.com)
}

\begin{abstract}
Online learning has been applied during the COVID 19 pandemic. This is one of the challenges in a teaching-learning activity that changes into a new process from face-to-face learning to online learning. It must be done by the teacher to deliver some materials to their students. One of the activities in teaching English language is reading comprehension. In this case, reading activity is useful for students related to this pandemic situation. Implementing online teaching by using online literature circles for the students at vocational high school is suitable to make them more creative and independent in the learning process. Teaching reading as an activity in learning English in vocational high school still uses an intensive method, it makes students are required to understand the reading text by being able to answer questions such as multiple choice or essays. Online literature circle activity that engages students to share their idea and discuss through a reading activity. The purpose of this study was to explore the experiences of students and the teacher perception of online literature circles through reading comprehension. The material that was applied in the research is about the application letter. The study involved 15 students at class twelve of network computer techniques at vocational high school in Ibrahimy 2 Sukorejo, Situbondo. Qualitative design is used in this study especially phenomenological research framework, with a deep interview by WhatsApp. The data was documented by using a message on WhatsApp.
\end{abstract}

Keywords: Reading comprehension; online literature circle; vocational high school.

One of the activities in teaching English is reading comprehension. It is necessary to improve the capability for understanding a text. Grellet (1981, p.03) states that reading comprehension is activities that focus on what we read, extracting the information that we need.

While the students are doing reading activities they should relate their prior knowledge of the word to make meaning. According to Elsa (2013, p.103), a good reader use prior knowledge to assess new information learned, then connect into other experience and use a useful strategy to make sure for comprehending the text. As readers make relations they may even feel like the characters in the books they are reading, or consider related experiences, and connect with the 
storyline or reread for words, sentences to comprehend the meaning. If students are not able to make relations, learning will only be an activity without any information they acquire. The readers' responses about the text will be a literal interpretation void of meaning. If students can flow up new learning and make connections, comprehension will enhance.

The goal of the reading activity is to get a message from the texts. The reader will know and catch the information of the texts due to reading comprehension. It is also related to some strategies for reading activities.

Several reading strategies are used to obtain information more quickly and accurately. Brown \& Lee (2015, p.401) describes the various reading comprehension strategies that can be applied in classroom learning techniques; a) identify the purpose of reading; b) use graphemic rules and patterns to aid in bottom-up decoding; c) silent reading techniques for improving fluency; d) skimming the text for the main idea; e) scan the text for specific information; $f$ ) semantic mapping or clustering, g) guessing the meaning; h) analyze vocabulary; i) distinguish between literal and implied meaning, $j$ ) capitalize on discourse makers to process relationship.

According to Brown \& Lee (2015, p. 401), all strategies of reading activity can help readers easier to get some information on the text through reading comprehension.

First, identify the purpose of reading. Many times we read the texts that have to know the purpose of reading something. We are as a reader should ask to ourselves about why we read and what are we looking for in reading. Efficient reading consists of clearly identifying the purpose of reading something.

Second, Use graphemic rules and patterns to aid in bottom-up decoding. It is useful for learners at the beginning level. The readers encounter in learning to read is making correspondences between spoken and written English. It needs hints and explanations about certain English orthographic rules and peculiarities. "Long" vowel sound in VCe (final silent e) patterns (late, time, bite, etc).

Third, silent reading techniques for improving fluency. it is necessary to apply to intermediate until advanced level students, but not at the beginning level because they are still struggling with the control of limited vocabulary and grammatical patterns. The rules that can be done by the teacher in this strategy are: it does not need to "pronounce", Try to visually perceive more than one word at a time, preferably phrases, Unless a word is crucial to global understanding, skip over it and try to infer its meaning from its context.

Fourth, skim the text for the main idea. It consists of quickly running one's eyes across a whole text (such as an essay, article, or chapter) for its gist. The advantage of skimming is being able to predict the purpose of the passage, the main topic, or the messages. Santamaria (2017) stated that Skimming for general meaning is an activity of reading the whole selection rapidly to determine its general purpose and content.

Fifth, scan the text for specific information. It means speed reading aiming to search particular information in a text. The reader is looking for names or dates, to find a definition of a key concept, or to list a certain number of supporting details.

Sixth, semantic mapping or clustering. The readers are grouping ideas into meaningful clusters.

Seventh, guessing the meaning. Some advantages of guessing the meaning are guessing the meaning of a word, guess a grammatical relationship, guess a discourse relationship, infer implied meaning, guess about cultural reference, and guess the content message.

Eighth, analyze vocabulary. It is the way for the reader to guess a word when they immediately do not recognize it. Some techniques are needed for helping readers to employ words are: look for prefixes, look for suffixes, look for familiar roots, look for grammatical context, and look at the semantic context. 
Ninth, distinguish between literal and implied meaning, and the last is capitalize on discourse makers to process relationship.

Brown \& Lee (2015, p.408) also describe two types of reading activities in the classroom; a) reading aloud and reading silently (silent reading); b) Intensive and extensive reading. Intensive reading activities tend to be more grammar, linguistic and semantic. While extensive reading is a reading activity that emphasizes general ability in reading a text.

Since the outbreak of the Covid 19 virus, many things have changed in the education aspect actually in teaching and learning process in Indonesia. One of them is by carrying out online learning or delivering online learning. This is of course related to technology and also the existence of an adequate internet connection so that learning can run well.

Online learning is different from e-learning. Online learning is the delivery of learning materials through technology with networks as a means of communication. While e-learning is also said to be blended learning, namely a learning approach using a combination of traditional or face-to-face learning using electronic learning media (Littlejohn \& Pegler, 2007, p. 226).

Media that can be used in the learning process in Indonesia include; TVs, digital projectors, computers, and others. Molinda (2005) adds that virtual learning is a form of distance learning through telecommunications and information technology, for example, the internet, CD-ROM.

Several platforms can be used by teachers as educators as a means of online or online learning. Bold learning can be used through the Zoom application, Google Classroom, Quipper, Zenius, edmodo, Schoology (Eriquez, 2014; Sicat, 2015; Iftakhar, 2016) and also by using short messages, namely through WhatsApp (So, 2016). Through Facebook and Instagram, virtual learning can also be carried out (Kumar \& Nanda, 2018).

\section{Online Literature Circle}

The literature circle is a method or concept of reading text online in a group manner. Daniels (2006) states that in literature, literature circles are also known as continuous reading or book clubs. Readers can choose the type of reading that they want. As a group, readers can share information, opinions, feelings, questions, and consider books, articles, journals, and other materials (Daniel, 2002, p.7).

The online literature circle on reading activities in small groups and then giving assumptions and responses according to the background knowledge they already have, (Cameron et al. 2012, p.1). The benefits of the literature circle method in learning get positive things through reading activities widely, combining experiences with a text

Table 1. Applying Online Literature Circle

\begin{tabular}{|c|c|}
\hline $\begin{array}{c}\text { Meeting } \\
1\end{array}$ & $\begin{array}{l}\text { The teacher explains how the learning } \\
\text { process will be delivered and brain- } \\
\text { storming with the students related to } \\
\text { the application letter material }\end{array}$ \\
\hline $\begin{array}{l}\text { Meeting } \\
2\end{array}$ & $\begin{array}{l}\text { The teacher provided some vocabularies } \\
\text { related to an application letter by quiz } \\
\text { on Google Form }\end{array}$ \\
\hline $\begin{array}{l}\text { Meeting } \\
3\end{array}$ & $\begin{array}{l}\text { The teacher explains the application let- } \\
\text { ter, its functions and its parts via Zoom. }\end{array}$ \\
\hline $\begin{array}{l}\text { Meeting } \\
4\end{array}$ & $\begin{array}{l}\text { Students were given examples of appli- } \\
\text { cation letter texts via goggle form and } \\
\text { also how to read the text according to } \\
\text { the correct intonation and pronuncia- } \\
\text { tion }\end{array}$ \\
\hline $\begin{array}{l}\text { Meeting } \\
5\end{array}$ & $\begin{array}{l}\text { Students were given examples of appli- } \\
\text { cation letter texts via goggle form and } \\
\text { also how to read the text according to } \\
\text { the correct intonation and pronuncia- } \\
\text { tion }\end{array}$ \\
\hline $\begin{array}{l}\text { Meeting } \\
6\end{array}$ & $\begin{array}{l}\text { Students were given the task to learn to } \\
\text { find examples of application letters from } \\
\text { other sources in a group that consist of } \\
\text { three students of each group, }\end{array}$ \\
\hline $\begin{array}{l}\text { Meeting } \\
7\end{array}$ & $\begin{array}{l}\text { Students read the application letter that } \\
\text { was found with their friends in a group } \\
\text { via Zoom. }\end{array}$ \\
\hline $\begin{array}{l}\text { Meeting } \\
\quad 8\end{array}$ & $\begin{array}{l}\text { Meeting the teacher provided feedback } \\
\text { to students' activity in each group }\end{array}$ \\
\hline
\end{tabular}


that is read; provide a positive impact on reading activities academically on reading comprehension, can increase the potential of readers in thoroughly reading activities.

This research is going to show the description of teacher and students' perception about the phenomenon in teaching English by online literature circle on reading comprehension class in the pandemic era.

The online literature circle that was applied in this research was done in eight meetings (Shown in Table 1). It has fourteen minutes of each meeting.

After the activity is completed, the teacher asks students to answer several questions about their perceptions of the use of online literature circles in the material application letter in the reading class.

An application letter is commonly referred to as a job application letter can also be known as a sales letter. This is because the author describes several offers for profiles, his ability to convince readers. The purpose of an application letter is to find a specific job that matches the interests and expertise of the author. Dhanny (1994, p.150) states that a job application letter contains experiences about education, work, special abilities possessed by the author so that he can get a certain job. Benton in Kumalasari journal sections of job application letters, among others; author's address, date when the application letter was made, the address of the intended company, opening greetings, contents of the letter, closing, closing greetings, full name, and signature of the author.

\section{Method}

This research is applied in qualitative research with a phenomenological study type. This research is part of a type of qualitative research. Husserl in Hasbiyansyah (2005) states that phenomenological research is a type of research that comes from a phenomenon that occurs in everyday life, let the phenomenon appear, and try to understand it.
The qualitative research model of phenomenology study is "a way of looking at things", which means through a phenomenon that occurs in the environment is based on a basic and a condition for all scientific activities, Brouwer (1984, p. 3). What and Berg (1995, p.417) state that Phenomenologist,... are not all in the business of trying to explain why people do what they do. Rather, they are interested in explaining how people do what they do; according to constructs they manage to organize their daily lives, especially their communications with each other. On the other hand, this study described an experience of the subject in a sequence phenomenon. According to Bagus (2002, p.236), phenomenology study is a kind of analysis descriptive and the introspection of a situation in direct experience.

This research was chosen to describe the perceptions of teachers and students through online literature circle learning in reading class at twelfth class on a network computer program. This process of learning activity one of an effort to repress the chain of Covid-19 spread on vocational high schools in Sukorejo.

The Data collection in this research was carried out by in-depth interviews with students in a twelfth class about the application of online learning literature circle in reading Application letter material. Interviews were conducted via indirect messages given to students via WhatsApp.

The data was collected through data collection in the form of interviews and analysis with the theory of Miles \& Huberman, (1994). This analysis has 3 stages, namely data reduction, data display, and concluding.

Miles \& Huberman, M (1994) stated that the reduction step is collecting the information that was needed from the interview results and then grouping the data. The data display step is the exposure of the data needed in the study. While concluding is obtained by the phenomena that occurred. 
The population of this research was 15 students of the network computer program at the twelfth class in 2020/2021 academic year.

The instrument of this research used eight questions to gain responses from the students. The questions include (1) as a student, have you ever participated in an online learning before? (2) How does your teacher deliver the learning material in online learning? (3) What applications or platforms does your teacher often use to deliver the learning material in online learning? (4) How do you feel as a student when receiving online literature circle in reading class? (5) What do you think about online learning? (6) As a student, what were your obstacles during the online learning? (7) As a student, do you prefer online or face-toface learning in class? (8) Please state your reason based on your answer number (7).

\section{Results and Discussion}

The result of this study was used to answer the students and teacher perception through an online literature circle on reading comprehension about application letter material in the twelfth class of network computer technique program in 2020/2021 academic year at ibrahimy 2 vocational high school in Sukorejo.

It was applied in a phenomenology study with a population of 15 students in class twelfth. It was represented by interviewing to get some data from the application of the online literature circle in reading comprehension. The responses of students to many questions are described in tables in this section.

Based on Table 2, the students gave their responses through their experiences in online learning process. Only a few of the students had experiences in online learning.

As an online learning was applied in the classroom, the students got some materials from the teacher via WhatsApp group that was created by the teacher (Table 3 ). They received files for them to learn from the teacher during the pandemic.

Some platforms that was used through
Table 3.The responses to item number 2

\begin{tabular}{|c|c|}
\hline $\begin{array}{l}\text { Question } \\
2\end{array}$ & $\begin{array}{l}\text { How does your teacher deliver the } \\
\text { learning material in online learning? }\end{array}$ \\
\hline Student 1 & It was easy to understand \\
\hline Student 2 & $\begin{array}{l}\text { The material was given as a file by } \\
\text { Google Classroom }\end{array}$ \\
\hline Student 3 & It delivered as a file \\
\hline Student 4 & The file was a resume of the material \\
\hline Student 5 & $\begin{array}{l}\text { It delivered by a file into Google } \\
\text { Classroom }\end{array}$ \\
\hline Student 6 & $\begin{array}{l}\text { It was little difficult to understand } \\
\text { because the time was limited }\end{array}$ \\
\hline Student 7 & It was clear enough \\
\hline Student 8 & It was deliver by whattssApp group \\
\hline Student 9 & It described by Zoom \\
\hline Student 10 & It used Google Classroom \\
\hline Student 11 & It delivered by WhatsAap \\
\hline Student 12 & The file was sent by Wa \\
\hline Student 13 & It used Zoom application \\
\hline Student 14 & The material was sent as a file \\
\hline Student 15 & It used Google Classroom \\
\hline
\end{tabular}

online teaching and learning are Google Classroom and WhatsApp group. A few of the platforms that are also applied in online learning is Zoom (Table 4).

Table 4. The responses to item number 3

\begin{tabular}{ll}
\hline Question 3 & $\begin{array}{l}\text { What applications or platforms does } \\
\text { your teacher often use to deliver the } \\
\text { learning material in online learning? }\end{array}$ \\
\hline Student 1 & Google Classroom \\
Student 2 & Classroom andWhasApp \\
Student 3 & Classroom andWhasApp \\
Student 4 & WhatsApp and Classroom \\
Student 5 & WhatsApp and Zoom \\
Student 6 & Classroom \\
Student 7 & WhatsApp \\
Student 8 & Zoom and WhatsApp \\
Student 9 & WhatsApp and Google Classroom \\
Student 10 & Zoom and WhatsApp \\
Student 11 & WhatsApp \\
Student 12 & Classroom \\
Student 13 & WhatsApp \\
Student 14 & WhatsApp and Google Classroom \\
Student 15 & Google Classroom \\
\hline
\end{tabular}


Table 5.The student perception of question number 4

Question How do you feel as a student when

4 receiving online literature circle in reading class?

Student 1 I was interesting enough

Student 2 I got more information

Student 3 Has a new experience

Student 4 I was more interesting

Student 5 I was so lucky

Student 6 Get a new challenge

Student 7 It was happybecause I can try to read by myself

Student 8 I feel prefer to like study English

Student 9 It was really exciting

Student 10 I can study with my friend

Student 11 Really interesting

Student 12 I can be easier to share with my friend

Student 13 It can minimize of feeling afraid for studying English

Student 14 It can help to understand English

Student 15 It was more interesting

Table 6. The responses to item number 5

Question 5 What do you think about online learning?

Student 1 I had to struggle a little in online learning

Student 2 Because it was not a face-to-face so it was little difficult to understand

Student 3 As in my opinion it was little difficult to understand

Student 4 I don't like because was difficult to understand and it was not really clear

Student 5 It has negative and positive effects; it could give more insights yet limited by time

Student 6 It was not clear and I struggled in studying

Student 7 I can get more time to study in my home

Student 8 It was lost more internet quota

Student 9 I got more insight

Student 10 To me, it can minimize to play a game online

Student In my opinion it was little difficult because

11 not all the students have smart phone

Student 12 This helps me use gadget in a right way

Student a smartphone can help when used

13 wisely, not for playing a game

Student It was useful enough in order I can

14 study more in my home

Student 15 It can help to understand the material
Based on the perception of the students on Table 5 was described that using literature circle as online learning got some advantages. They felt more confident in learning English, because they can share the problem with their friends. The students also can ask their difficulties such as some meaning of vocabularies, share the massage of the text, etc.

Online learning through the students' perception on Table 6 was described that some of the students did not get a clear explanation. They prefer to learn by face-to-face than online learning. Because they can get more intensive time to learn by face-to-face with the teacher in the class. However, there are also students stated that online learning can minimize the activity to play a game online. They can study independently by online and also get some sources from online.

As seen in the table above, online learning has disadvantages based on the students' perception. They stated that while doing online learning they have to prepare enough internet quota and stay in a proper

Table 7.The responses to item number 6

Question 6 As a student, what were your obstacles during the online learning?

Student 1 When the electricity was off

Student 2 The internet quota was limit

Student 3 Internet quota was not enough

Student 4 Not all the students have a smart phone

Student 5 The signal was so difficult

Student 6 It was lost much internet quota

Student 7 It needed much internet

Student 8 The Wi-Fi was so difficult to find in my home

Student 9 Not all students have smart phone

Student 10 I always borrow my sisters phone

Student 11 The signal was so good

Student 12 The phone's battery is low

Student 13 The Wi-Fi was so difficult to find

Student 14 I have not enough internet

Student 15 The internet was limit 
Table 8.The responses to item number 7

Question 7 As a student, do you prefer online or face-to-face learning?

\begin{tabular}{|c|c|}
\hline Student 1 & I prefer like to study face-to-face \\
\hline Student 2 & I like to study in class \\
\hline Student 3 & $\begin{array}{l}\text { Prefer like to study in the class with } \\
\text { friends }\end{array}$ \\
\hline Student 4 & I like to study face-to-face \\
\hline Student 5 & $\begin{array}{l}\text { It was more interesting to study in } \\
\text { the class with friends }\end{array}$ \\
\hline Student 6 & I like to study in the class \\
\hline Student 7 & Face to face \\
\hline Student 8 & Prefer like to study in the class \\
\hline Student 9 & I like to study face-to-face \\
\hline Student 10 & Face to face in the class \\
\hline Student 11 & I prefer like to study face-to-face \\
\hline Student 12 & Studying in the class \\
\hline Student 13 & Face to face \\
\hline Student 14 & Prefer to study in the class \\
\hline Student 15 & Studying face-to-face \\
\hline
\end{tabular}

place that can get the best signal. Another reason is not all the students have a smartphone.

Based on the table above the students

Table 9.The responses to item number 8

\begin{tabular}{ll}
\hline Question 8 & $\begin{array}{l}\text { Please state your reason in the an- } \\
\text { swer based on your answer number } \\
7 .\end{array}$ \\
\hline Student 1 & understand better \\
Student 2 & makes things clearer \\
Student 3 & makes things clearer \\
Student 4 & More interesting \\
Student 5 & Can enjoy learning more \\
Student 6 & Get more pocket money from parents \\
Student 7 & More clear in the class \\
Student 8 & Fell so happy when meet friends \\
Student 9 & Get more time to share with friends \\
Student 10 & have more time to discuss with friends \\
Student 11 & Can get more experience \\
Student 12 & Can play with friends \\
Student 13 & More understand \\
Student 14 & It helps understand the explanation \\
& from teacher \\
Student 15 & It does not need to use any internet quota
\end{tabular}

prefer face-to-face learning in the class to online learning. They felt more interesting meet with their friend in the class. They can get clearer explanations from the teacher in the class.

Ferdiansyah (2020) stated that the literature circle becomes an appropriate strategy of teaching especially for reading comprehension in the pandemic era. It also promoted students' engagement and empowerment of reading activity in classroom. In the previous study, Mark in Widodo (2016) mentioned that students' investigated that literature circle was enhanced students extensive reading in a book discussion. Nolasco (2009) stated that literature circle enhanced students' comprehension through extensive reading in expository, scientific text.

Related to the previous study, the researcher applied the online literature circle in reading class through students and teacher perception. It showed that based on the findings of Table 1.2, they have never gotten experience in online learning before pandemic situation, but there are four students give responses they have ever done online learning before pandemic situation.

It also can be seen from Table 1.3 from the responses of the students. It relates to the way the teacher delivers the learning material in online learning, which was via WhatApp, Google Classroom, Zoom, and it was clear enough.

The students' responses as seen in Table 1.4 showed that most of the teachers used a platform by WhatsApp. But it also used Zoom application and classroom.

Findings in Table 1.5 show that some students are giving their positive responses. As it is a new experience, this enables students to share their problem about the text in reading activity, and help them in learning English through asking their friends in a group.

Related to online learning, the students gave their responses as seen in Table 1.6. 6 students responded that they are not excited about online learning and 9 students gave 
positive responses about online learning. Negative responses of the students because online learning is not clear enough of their understanding. Yet, the study also revealed positive responses of the students in online learning, that the students felt more freely in searching some sources, have a little time to play an online game, and get more time to study hard.

Nevertheless, some students prefer to choose teaching and learning process should be done in the classroom as a normal situation. They can study seriously in the class with their friends; they are more understand of the teacher's explanation, can get a salary from their parents, and they do not need to purchase more internet data. Those are based on the students' responses on the Table 1.7 and Table 1.8.

The teacher's representation of the online literature circle on reading comprehension is more excited in doing teaching-learning. It can make the students more creative and independent to study at home. However, it has also weaknesses in teaching online literature circles on reading comprehension.

\section{Conclusion}

There were 15 students as participants of this research. That was based on the applying of online literature circle on the reading comprehension of application letter in class twelfth network computer technique in vocational high school of Sukorejo in the 2020/2021 academic year. It is one of the solution to continue the teaching and learning process during the situation. For other researcher also can continue the online literature circle on their research.

\section{Acknowledgment}

The researcher would like to deliver deep gratitude to all the students of the network computer technique in vocational high school Sukorejo were included to data of reading comprehension through online literature circle. Huge thanks also to Mr. Mahrus as the headmaster and Mr. Qomar as the English teacher who made their time for my research conduct.

\section{References}

Bagus, Lorens. (2002). Kamus Filsafat.Jakarta: GramediaPustakaUtama.s.

Brown, H. D, \& Lee, H. (2015). Teaching by Principles; An Interactive Approach To Language Pedagogy, Fourth Edition: Pearson Education, Inc.

Brouwer, M. A. W. (1984). Psikologi Fenomenologis. Jakarta: Gramedia.

Cameron, S., Murray, M., Hull, K., \& Cameron, J. (2012). Engaging fluent readers using literature circles. Literacy Learning: The Middle Years, 20(1), 1-8.

Daniels, H. (2006). What's the next big thing with literature circles? Voices from the Middle, 13(4), 10-15.

Dhanny, R.C. (1995). Practical Bussiness Correspondence. Visipro, Jakarta.

Elsa. M.D. B.S., M.Ed. (2013). An Investigation of Literature Circles as a Means to Promote Reading Comprehension. Texas Tech University

Ferdiansyah S, Ridho MA, Sembilan FD, Sembilan FD, Zahro SF. Online literature circles during the COVID-19 pandemic: Engaging undergraduate students in Indonesia. TESOL J. 2020;11:e544. https://doi.org/10.1002/tesj.544

Grellet. F. (1981). Developing reading skills, a practical guide to reading comprehension exercises. London: Cambridge University Press.

Iftakhar, S. (2016). Google Classroom: what works and how? Journal of Education and Social Sciences.

Kumalasari, R., Rufinus, A., Husin, S.(2013). Using Writing Process in Teaching an Application Letter through Group Work for Vocational Students. 
Jurnal Pendidikan dan Pembelajaran Khatulistiwa, 2(5),

Kumar, V., \& Nanda, P. (2018). Social Media in Higher Education. International Journal of Information and Communication Technology Education. https://doi. org/10.4018/ijicte.2019010107

Littlejohn, Allison and Chris Pegler. (2007) Preparing for Blended E-Learning. Oxon: Routledge

Miles, M. B., \& Huberman, M. (1994). Qualitative Data Analysis Second Edition. SAGE Publications.

Molinda, M. (2005), Instructional Technology and Media for Learning. New Jersey Colombus, Ohio

Nolasco, J. L. (2009). Effects of literature circles on the comprehension of reading expository texts (Caldwell College). ProQuest Dissertations and Theses, 51. http://search.proquest.com/ docview $/ 305172713$ ? accountid $=8203$

Santamaria, J. C. (2017). Better Reading ENGLISH. The United States.

Sicat, A. S. (2015). Enhancing College Students' Proficiency in Business Writing Via Schoology. International Journal of Education and Research.

So, S. (2016). Mobile instant messaging support for teaching and learning in higher education. Internet and Higher education.https://doi.org/10.1016Zj. iheduc.2016.06.001

Widodo, H. P. (2016). Engaging students in literature circles: Vocational English reading programs. The Asia-Pacific Education Researcher, 25, 347-359. https://doi.org/10.1007/s40299-0150269-7. 